\title{
KAJIAN SOSIOLOGI HUKUM TERHADAP PENYALAHGUNAAN NARKOTIKA OLEH ANAK
}

\author{
Wahyu Rasyid \\ Fakultas Hukum \\ Universitas Muhammadiyah Parepare, Jalan Jenderal Ahmad Yani KM 6 Kota Parepare \\ Kode Pos 91113, Telpon : 0421-22757/Fax 0421-2554 Sulawesi Selatan Indonesia \\ Email: wahyu_rasyid03@yahoo.com
}

\begin{abstract}
The aim of this research is to know (1) Efforts to prevent abuse of narcotics by children and to know (2) Factors influencing the effort of prevention of narcotics abuse by children. (3) Community participation in prevention of narcotics abuse by children. This research was conducted in Makassar District Court, Makassar City area. This type of research is empirical research with the approach of legal sociology. Types of data consisting of primary data and secondary data obtained through interviews and analyzed and then presented in the form of descriptive. The results showed that (1) Efforts to prevent abuse of narcotics by children in the city of Makassar has been running, but not yet effective, it is known from the number of children who abuse drugs continue to increase both in quality and quantity from year to year other than that harmonization apparatus law and community participation is still not optimal, so the results are not yet realized. (2) Factors affecting the effectiveness of worldviews and efforts of penal oriented, public understanding and perception about the dangers of narcotics abuse by children are minimal, and the level of public confidence in the legal apparatus is still low, the availability of supporting facilities and infrastructure is limited. (3) The lack of optimal participation of the community is caused by the working relationship of the law enforcement apparatus with the community has not been running well.
\end{abstract}

Keywords: Sociology study, narcotics abuse,

Abstrak: Penelitian ini bertujuan untuk mengetahui (1) Upaya pencegahan penyalahgunaan narkotika oleh anak dan untuk mengetahui (2) Faktor-faktor yang mempengaruhi upaya pencegahan penyalahgunaan narkotika oleh anak.(3) Peran serta masyarakat dalam upaya pencegahan penyalahgunaan narkotika oleh anak. Penelitian ini dilaksanakan di Pengadilan Negeri Makassar, wilayah Kota Makassar. Tipe penelitian ini adalah penelitian empiris dengan pendekatan sosiologi hukum. Jenis data yang terdiri atas data primer dan data sekunder yang diperoleh melalui wawancara dan dianalisis kemudian disajikan dalam bentuk deskriptif. Hasil penelitian menunjukkan bahwa (1) Upaya pencegahan penyalahgunaan narkotika oleh anak di kota Makassar sudah berjalan, namun belum efektif, hal itu diketahui dari jumlah anak yang melakukan penyalahgunaan narkotika masih terus meningkat baik secara kualitas maupun kuantitas dari tahun ke tahun selain itu harmonisasi aparat penegak hukum dan peran serta masyarakat masih belum optimal, sehingga hasil yang diharakan belum bisa terwujud. (2) Faktor yang mempengaruhi 
efektivitas cara pandang dan upaya yang berorientasi sarana penal, pemahaman dan pandangan masyarakat tentang bahaya penyalahgunaan narkotika oleh anak amasih minim, dan tingkat kepercayaan masyarakat terhadap aparat hukum masih rendah, ketersedian fasilitas sarana dan prasarana yang mendukung masih terbatas. (3) Belum optimalnya peran serta masyarakat disebabkan oleh hubungan kerja aparat penegak hukum dengan masyarakat belum berjalan baik.

Kata Kunci: Kajian Sosiologi, penyalahgunaan narkotika,

\section{LATAR BELAKANG}

Secara formal dalam konstitusi Negara Republik Indonesia disebutkan bahwa Indonesia sebagai Negara hukum yang sebagaimana diatur dalam Pasal 1 ayat 3 UUD NRI Tahun 1945 bahwa Indonesia adalah Negara hukum. Dikaitkan dengan konsepsi bernegara hukum maka hukum haruslah menjadi instrument atau sarana yang efektip untuk mencapai tujuan bernegara hukum. Bagaimana menciptakan atau mewujudkan hukum sebagai instrument atau sarana yang efektip untuk mencapai tujuan bernegara hukum tentunya tidak terlepas dari kebijakan pembangunan hukum yang dilakukan guna melahirkan atau mewujudkan sebuah sistem hukum yang utuh dan komprehensif. ${ }^{1}$ Sebagai Negara hukum, fenomena permasalahan hukum tidak pernah surut dalam kehidupan bermasyarakat. Salah satu fenomena permasalahan hukum di Indonesia yang

\footnotetext{
1 Aminuddin Ilmar, Membangun Negara Hukum Indonesia, (Makassar: Phinatama Media, 2014) hlm. 5.
}

sangat mengkhawatirkan yakni tindak pidana penyalahgunaan narkotika. Masyarakat Indonesia dihadapkan pada keadaan semakin maraknya penggunaan berbagai macam jenis narkotika secara tidak sah dan melawan hukum.

Hal tersebut diperparah dengan peredaran narkotika yang semakin meluas di semua lapisan masyarakat bahkan pada saat sekarang ini peredaran narkotika tidak saja menjadi kendala di kota-kota besar tetapi mulai merembes ke pedesaan. Kemajuan teknologi dan perkembangan penyalahgunaan narkotika yang semakin meningkat dan bervariasi motif penyalahgunaan dan pelakunya, dapat dilihat dari cara menanam, memproduksi, menjual, memasok dan mengkonsumsinya serta kalangan pelaku penyalahgunaan narkotika tersebut.

Tindak pidana penyalahgunaan narkotika telah menjangkit semua lapisan masyarakat mulai dari kalangan masyarakat biasa, kalangan Pengawai Negeri Sipil, 
kalangan Pengusaha, kalangan politisi, kalangan akademisi sampai pada aparat penegak hukum pun terjangkit tindak pidana narkotika. Dewasa ini berdasarkan hasil pengamatan yang ada rata-rata adalah anak muda bahkan telah menyentuh hingga ke kalangan anak-anak yang merupakan penerus cita-cita bangsa dan Negara pada masa yang akan datang. Secara yuridis, anak yang melakukan penyalahgunaan narkotika di kategorikan sebagai pelaku, tetapi yang perlu diingat adalah penyalahgunaan narkotika dikualifikasikan sebagai crime without victimyang berarti korban kejahatannya adalah pelaku itu sendiri sama halnya tindak pidana perjudian selain menjadi pelaku tindak pidana yang sekaligus juga menjadi korban.

Kuantitas tindak pidana narkotika, semakin hari semakin meningkat baik pelaku pengedar maupun korban penyalahgunaan narkotika hal yang paling memprihatinkan adalah yang menjadi pelaku pengedar adalah anak-anak. Namun yang perlu dicermati bahwa anak yang menjadi pelaku penyalahgunaan narkotika dalam hal dimaksud (pengedar narkotika) adanya faktor eksternal yang menjadi pelaku utama adalah orang dewasa dengan cara anak disuruh, diberi atau dijanjikan sesuatu, diberikan kesempatan, dianjurkan, diberikan kemudahan, dipaksa dengan ancaman, dipaksa dengan kekerasan, dengan tipu muslihat, atau dibujuk.

Upaya penanggulangan oleh aparat penegak hukum terhadap tindak pidana narkotika yang dilakukan oleh anak secara kuantitas menunjukkan peningkatan, namun hal tersebut belum bisa menurunkan intensitas tindak pidana penyalahgunaan narkotika. Dewasa ini, lembaga penegak hukum (Kepolisian, Kejaksaan, Hakim/Pengadilan) belum menunjukkan perannya secara optimal sebagai representasi dari Negara. Harapan masyarakat agar lembaga hukum untuk lebih transparan guna mencerminkan kewibawaan lembaga hukum sehingga kepercayaan masyarakat kepada kinerja penegak hukum akan menentukan efektivitas hukum itu sendiri.

Harus disadari bahwa masalah penyalahgunaan narkotika yang dilakukan oleh anak adalah suatu problema yang sangat kompleks, oleh karena itu diperlukan upaya dan dukungan dari semua pihak agar dapat mencapai tujuan yang diharapkan, karena pelaksanaan undang-undang, sangat tergantung pada partisipasi semua pihak baik pemerintah, aparat keamanan, keluarga, lingkungan, sebab hal tersebut tidak dapat hilang dengan sendirinya meskipun telah 
dikeluarkan undang-undang yang disertai dengan sanksi yang keras. Upaya pencegahan dan pemberantasan dapat dilakukan dengan penegakan hukum tindak pidana narkotika, faktor yang mempengaruhi proses penegakan hukum adalah faktor hukumnya sendiri, faktor penegak hukum, faktor sarana atau fasilitas, faktor masyarakat, faktor budaya. ${ }^{2}$

\section{METODE PENULISAN}

\section{Tipe dan Sifat Penelitian}

Tipe penelitian ini adalah penelitian hukum normatif dan empirik yakni tipe yang menitikberatkan pada upaya dan factor pencegahan masalah narkoba dikaitkan dengan Undang-undang No. 35 Tahun 2009 Tentang Narkotika. Penelitian ini bersifat deskriptif yaitu yang dimaksudkan untuk memberi gambaran secara jelas dan objektif mengenai masalah yang akan diteliti.

\section{Jenis Penelitian}

Adapun jenis data yang digunakan dalam penelitian ini adalah data primer dan data sekunder.Data Primer, yaitu data yang diperoleh secara langsung dari responden di lapangan atau lokasi penelitian. Responden yang dimaksud yakni wawancara dengan para hakim dan para jaksa yang pernah

2 Soerjono Soekanto, Factor-Faktor Yang Mempengaruhi Penegakan Hukum. (Jakarta: Rajawali Press 2007) hlm. 5. menangani, memeriksa perkara tindak pidana narkotika dimana penjatuhan pidananya dibawah minimum. Data sekunder diperolehdata yang diperoleh melalui studi pustaka berupa buku, dokumen, peraturan perundang-undangan, majalah, karya ilmiah, surat kabar, internet dan lain-lain yang berhubungan dengan objek penelitian.

\section{Teknik Pengumpulan Data}

Data yang digunakan dalam penelitian ini adalah data primer dan data sekunder yang diperoleh dengan menggunakan cara, yaitu Data Primer yang diperoleh melalui wawancara yang dilakukan kepada para responden mengenai penjatuhan pidana dibawah minimum dalam perkara tindak pidana narkotika. Data Sekunder yang diperoleh melalui studi dokumen, yaitu mengumpulkan data sekunder yang relevan dengan objek penelitian.

\section{Analisis Data}

Data yang telah diperoleh melalui kegiatan penelitian yang dianalisis secara kualitatif didukung oleh data kuantitatif, kemudian disajikan secara deskriptif yaitu dengan menjelaskan dan menggambarkan sesuai permaslahan yang erat kaitannya dengan penelitian ini. 


\section{PEMBAHASAN}

Salah satu penyebab fenomena penyalahgunaan narkotika yang dilakukan oleh anak adalah terjadi pergeseran nilainilai yang dianut oleh masyarakat, disebabkan oleh semakin pudarnya social order atau sistem pengawasan sosial masyarakat, dimulai dari pergeseran nilai pada lingkup lingkungan terkecil hingga lingkungan terbesar, pergeseran nilai-nilai tersebut dimulai di lingkungan kehidupan keluarga, lingkungan sekolah, sampai pada lingkungan social masyarakat.

Apabila kita cermati, sesungguhnya anak merupakan anggota keluarga yang paling rentan, karena anak kerap menjadi korban dari prilaku negative yang diperoleh dari keluarga maupun lingkungannya. Keluarga dan lingkungan sekitarnya mempunyai potensi yang besar untuk berperan secara aktif dalam menlindungi anak dalam segala hal termaksud yang menyimpang.Anak kerap dipertontonkan dengan situasi bersifat negative yang sepatutnya tidak dilihat oleh anak dan yang paling memperhatikan keluarga dan lingkungan sekitar tidak memperdulikan hal demikain, padalah masa depan kita terletak pada seberapa maksimal perhatian kita pada anak-anak kita. Anak-anak yang yang berada pada masa remaja sedang mengalami kegoncangan jiwa, jadi tindakan yang bersifat menyimpang yang dilakukan oleh anak-anak adalah suatu bentuk manifestasi dari masa kenakalan remaja tersebut. Perbuatan meyimpang yang mereka lakukan tanpa ada maksud untuk merugikan orang lain. Perilaku menyimpang anak-anak tidak dapat dipandang mutlak samadengan perbuatan meyimpang yang dilakukan oleh orang dewasa. Meskipun pada prinsipnya jenis perbuatannya sama, namun tingkat kematangan fisik dan emosi anak masih labil, dan masa depan anak seharusnya dapat menjadi pertimbangan dalam hal menentukan perlakuan yang tepat terhadap mereka.

Dalam Kitab Undang-Undang Hukum Pidana (KUHP) suatu perbuatan kejahatan disyaratkan pelaku harus menyadari akibat dari perbuatannya serta pelaku mampu bertanggungjawab terhadap perbuatan tersebut dengan demikian, tindakan yang menyimpang yang dilakukan oleh anak tidak dapat dikatakan sebagai kejahatan murni.Ini didasari asumsi bahwa mereka yang berada dalam usia anak tidak dapat melakukan kejahatan atau doli incapaxdan tidak dapat secara penuh bertanggungjawab atas tindakannya Tindakan menyimpang yang dilakukan oleh anak saat ini sering terjadi di 
masyarakat salah satunya adalah penyalahgunaan narkotika, dalam hal anak sebagai penyalahgunaan narkotika yang perlu diingat bahwa anak bukan hanya sebagai pelaku tapi juga sebagai korban (crime without victim).

Namun dalam beberapa perkaraperkara anak sebagai penyalahgunaa narkotika masih saja anak akan dihadapkan pada proses hukum, kasus anak tidak diupayakan diversi secara maksimal yang berujung pada proses persidangan bahkan tidak jarang diputus pidana penjara dan tidak diputus untuk menjalani rehabilitasi. Proses penghukuman yang diberikan kepada anak dengan memasukkan anak ke dalam penjara ternyata tidak berhasil menjadikan anak jera dan menjadi lebih baik. Penjara justru seringkali membuat anak semakin professional dalam melakukan tindak kejahatan. ${ }^{3}$ Dalam hal ini aparat penegak hukum dalam mengimplemetasikan Undangundang Nomor 11 Tahun 2012 tentang Sistem Peradilan Pidana Anak yang terkait dengan Undang-Undang Nomor 35 Tahun 2009 tentang Narkotika tidak dilaksanakan secara optimal.

\footnotetext{
3 Nur Hidayati, "Peradilan Pidana Anak Dengan Pendekatan Keadilan Restorative dan Kepentingan Terbaik Bagi Anak," Jurnal Pengembangan Humaniora, Vol. 13 No. 2, (Agustus 2013) : 146.
}

Penyebab penyalahgunan narkotika disebabkan oleh beberapa hal seperti, karena di dorong rasa ingi tahu atau iseng-iseng, menunjukkan rasa solidaritas terhadap teman yang juga mengunakan narkotika, untuk menghilangkan rasa kegelisahan, menunjukkan jati diri (berani mencoba sesuatu yang berbahaya). Anak yang menggunakan narkotika secara tidak legal dikelompokkan kedalam tiga keinginan yaitu: ${ }^{4}$

Pertama, Mereka yang ingin mengalami (the experience seekers) yaitu ingin memperoleh pengalaman baru dan sensasi dari akibat pemakaian narkotika;

Kedua, Mereka yang bermaksud menjauhi atau mengelakkan realita hidup (the oblivion seekers) yaitu mereka yang menganggap keadaan terbius sebagai teempat pelarian terindah dan ternyaman.

Ketiga, Mereka yang ingin merubah kepribadiannya (personality change) yaitu mereka yang beranggapan menggunakan narkotika dapat merubah kepribadian, seperti menjadi tidak kaku dalam pergaulan.

$$
\text { Dalam beberapa kasus }
$$
penyalahgunaan narkotika yang dilakukan oleh anak, ada beberapa kategori anak;

\footnotetext{
${ }^{4}$ Soejono Dirdjosisworo, Pathologi Sosial, (Bandung: Alumni, 1982) hlm. 70-71.
} 
Pertama, Anak yang menjadi korban penyalahgunaan narkotika adalah mereka yang karena dibujuk, diperdaya, ditipu, dipaksa dan/atau diancam untuk menggunakan narkotika.

Kedua, anak yang menjadi penyalahguna narkotika adalah mereka yang menggunakan narkotika secara melawan hukum, menanam, memelihara, mempunyai atau menguasai, memiliki dan menyimpan untuk dimiliki narkotika.

Ketiga, anak sebagai pecandu narkotika adalah mereka (anak) yang menggunakan atau meyalahgunakan narkotika dalam keadaan ketergantungan pada narkotika.

Keempat, anak sebagai pengedar narkotika adalah anak yang tanpa hak atau melawan hukum menawarkan untuk dijual, menjual, membeli, menerima, menjadi perantara dalam jual beli, menukar atau menyerahkan narkotika.

Anak yang menjadi penyalahguna narkotika memerlukan perhatian yang prioritas baik dari pihak keluarga maupun pemerintah. Terutama mereka (anak) yang sudah masuk kategori pencandu narkotika dan pengedar narkotika. Anak yang menjadi pecandu narkotika memerlukan penanganan khusus karena untuk memulihkan/ menyembuhkan pecandu narkotika sangat sulit karena akibat dari penggunaan narkotika menimbulkan adiksi (ketagihan) yang pada akhirnya pada tahap dependensi (ketergantungan) sehingga memerlukan waktu yang tergolong lama.

Bagi anak yang menjadi pengedar hal yang perlu disadari oleh penegak hukum, anak sebagai pelaku penyalahguna (pengedar) narkotika adalah korban karena anak belum mampu mengoptimalkan kemampuan berpikirkan untuk membedakan antara baik dan buruk suatu perbuatan yang dilakukan untuk masa depan mereka sehingga penanganan kasus anak oleh penegak hukun mempertimbangkan "kepentingan terbaik" anak. Anak harus diperlakukan secara khusus, hal ini mengingat sifat dan psikis anak dalam beberapa hal tertentu memerlukan "perlakuan khusus" serta perlindungan khusus pula terutama pada tindakan yang dapat merugikan perkembangan mental maupun jasmani.

Aparat penegak hukum (kepolisian, kejaksaan, hakim) seharusnya lebih mengedepankan pendekatan keadilan restoratif. Disinilah aparat penegak hukum dituntut untuk memiliki integritas, profesionalitas dalam menjalankan 
profesinya seperti memiliki keterampilan dalam mengambil tindakan, kemampuan berpikir dalam mencari pemecahan masalah, wawasan atau cara pandang aparat penegak hukum dalam memahami keterkaitan antara perkembangan ilmu hukum dan perkembangan masyarakat dan juga adanya koordinasi dan harmonisasi yang baik antar lembaga penegak hukum agar penegakan hukum tidak hanya terfokus pada pemberantasan peredaran narkotika secara tidak sah dan melawan hukum namun pencegahan dini agar penyalahgunaan narkotika oleh anak tidak terjadi.

Dalam mengoptimalkan upaya pencegahan dan penanggulangan penyalahgunaan narkotika oleh anak tidak sebatas hanya pada penegak hukum tapi juga peran serta masyarakat.. Namun kendala yang dihadapi adalah rendahnya tingkat kepercayaan masyarakat dan kewibawaan aparat penegak hukum khususnya arapat kepolisian, pemahaman masyarakat tekait issu penyalahgunaan narkotika oleh anak, sarana dan prasarana pendukung.

Dalam kaitannya dengan peran serta masyarakat yang tidak melaporkan adanya tindak pidana narkotika tergantung pada tingkat kewibawaan dan kepercayaan masyarakat terhadap penegak hukum. Factor kepercayaan terhadap penegak hukum bermuara pada etika moral penegak hukum (sikap personal). Semakin tinggi tingkat kepercayaan masyarakat terhadap aparat penegak hukum maka akan semakin tinggi pula motivasi masyarakat untuk berperan serta sehingga tercipta sebuah pengawasan sosial.

Peran serta masyarakat dalam hal pelaporan tentang adanya kepemilikan, penyimpanan, penggunaan narkotika secara tidak sah adalah wujud penegakan hukum yang berfungsi sebagai pengawasan social. Perlindungan terhadap masyarakat yang melakukan peran serta merupakan hak individual yang harus dilindungi oleh aparat penegak hukum. Namun dalam beberapa kasus pelaporan oleh masyarakat justru menimbulkan rasa kekhawatiran dengan prsoses hukum yang berbelit-belit dan menyita waktu masyarakat sebagai pelapor dan juga berdasarkan pengamatan dengan melihat beberapa kasus narkotika, masyarakat merasa aparat penegak hukum kurang tanggap terhadap laporan mereka padahal, masyarakat selama ini telah berperan dengan memberikan informasi terkait masalah penyalahgunaan narkotika, merasa tidak ditanggapi laporannya masyarakat menjadi curiga bahwa aparat penegak hukum ikut terlibat atau mengambil 
keutungan materi dalam penyalahgunaan narkotika. Pengamatan public berdasarkan pengamatan terhadap konsistensi penegakan hukum akan tercipta norma-norma social yang dijunjung tinggi, sehingga normanorma social tersebut sebagai sarana pengendalian social. Agar masyarakat mau berpartisipasi aktif, diperlukan syarat ${ }^{5}$ :

Pertama, Adanya aparat penegak hukum yang akomodatif, simpatik, dan mampu mengajak masyarakat berpartisipasi. Kedua, Instansi pemerintah terkait harus dapat bekerja sama secara transparan dengan LSM atau lembaga social terkait lainnya.

Ketiga, Perilaku aparat penegak hukum yang teruji dan bekerja dengan jujur, professional, serta kebal terhadap sogok dan suap. keempat, Penerpana hukum secara tegas, konsekuen, konsisten dan transparan. Keempat, Adanya petunjuk atau pedoman untuk berpartisipasi bagi masyarakat dari semua instansi terkait agar partisipasi masyarakat terarah dan efektif.

Peran serta masyarakat sangat dibutuhkan untuk memberantas penyalahgunaan dan peredaran gelap narkotika, karena tanpa dukungan

${ }^{5}$ Badan Narkotika Nasional, Petunjuk Teknik Advokasi Bidang Pencegahan Penyalahgunaan Narkoba Bagi Lembaga/Instansi, (Jakarta: BNN RI, 2010) hlm. 36. masyarakat maka segala usaha dan kegiatan penegakan hukum akan mengalami kegagalan. Disinilah pentingnya mengubah bentuk pandangan, reaksi, sikap tingkah laku masyarakat dalam melihat kejahatan khususnya terhadap penyalahgunaan narkotika yang dilakukan oleh anak karena reaksi masyarakat terhadap kejahatan ternyata menunjukkan hubungan "signifikan" antara reaksi masyarakat dengan terjadinya kejahatan. Seperti sintesa yang mengatakan "semakin besar reaksi masyarakat terhadap kejahatan, maka semakin kecil terjadinya kejahatan", begitu pula sebaliknya, "semakin kecil reaksi masyarakat terhadap kejahatan, maka semakin tumbuh suburlah kejahatan". 6

Selain memberikan kewenangan yang besar terhadap penegak hukum, khususnya BNN, Undang-Undang No. 35 Tahun 2009 juga mewajibkan masyarakat untuk berperan aktif dalam upaya pencegahan dan pemberantasan penyalahgunaan dan peradaran gelap narkotika. Masyarakat dijadikan seperti penyelidik dengan cara mencari, memperoleh, dan memberikan informasi dan mendapatkan pelayanan dalam hal-hal tersebut. Undang-undang No. 35 Tahun 2009 tentang Narkotika Pasal 104

6 Teguh Prasetyo. Kriminalisasi Dalam Hukum Pidana. (Jakarta. Nusa Media. 2011) hlm. 13-14. 
menegaskan bahwa masyarakat mempunyai kesempatan yang seluas-luasnya untuk berperan serta membantu pencegahan, pemberantasn penyalhgunaan dan peredaran gelap narkotika dan Prekursor Narkotika.

Peran serta masyarakat dalam upaya penanggulangan tindak pidana penyalahgunaan narkotika oleh anak dapat ditandai dengan adanya hak dan tanggungjawab dalam melaporkan adanya tindak pidana penyalahgunaan narkotika disekitar lingkungannya kepada aparat penegak hukum. Dalam Undang-undang Nomor 35 Tahun 2009 Tentang Narkotika peran serta masyarakat dimuat dalam BAB XIII Pasal 104 sampai demgan Pasal 108.

\section{Dalam BAB XIII tentang peran serta} masyarakat disebutkan tengan hak dan tanggungjawab masyarakat dalam pencegahan dan pemberantasan tindak pidana narkotika sebagaimana dalam Pasal 105 Undang-undang Nomor 35 Tahun 2009 Tentang Narkotika:

"Masyarakat mempunyai hak dan tanggungjawab pencegahan dan pemberantasan penyalahgunaan dan peredaran gelap narkotika dan precursor Narkotika”.

Penjelasan lebih lanjut mengenai bentuk perwujudan hak masyarakat dalam upaya pencegahan dan pemberantasan Narkotika tercantum dalam Pasal 106 UU No. 35 Tahun 2009 Tentang Narkotika.

"hak masyarakat dalam upaya pencegahan dan pemberantasan penyalahgunaan dan peredaran gelap Narkotika dan Prekursor Narkotika diwujudkan dalam bentuk:

a. Mencari, memperoleh, dan memberikan informasi adanya dugaan telah terjadi tindak pidana Narkotika dan Prekursor Narkotika;

b. Memperoleh pelayanan dalam mencari, memperoleh, dan memberikan informasi tentang adanya dugaan telah terjadi pidana Narkotika dan Prekursor Narkotika kepada penegak hukum atau BNN yang menangani perkara pidana Narkotika dan Prekursor Narkotika;

c. Menyampaikan saran dan pendapat secara bertanggungjawab kepada penegak hukum dan BNN yang menangani perkara tindak pidana Narkotika dan Prekursor Narkotika;

d. Memperoleh jawaban atas pertanyaan tentang laporannya yang diberikan kepada penegak hukum dan BNN;

e. Memperoleh perlindungan hukum pada saat yang bersangkutan melaksanakan haknya atau dimintai hadir dalam proses peradilan.

Bentuk-bentuk peran serta masyarakat dalam upaya penanggulan Tindak Pidana narkotika anatara lain:

Pertama, Pencegahan tindak pidana narkotika. kedua, Kewajiban melaporkan 
tindak pidana narkotika. Ketiga, Jaminan keamanan dan perlindungan hukum. Keempat, Pengembangan Kelembagaan Masyarakat. Kelima, Pelaksanaan program kuratif dan program Rehabilitatif dan terakhir Mengawasi uapaya penangkapan adanya pelanggaran, penahanan tersangka, jalannya penuntutan, jalannya eksekusi hukuman dan mengawasi pemusnahan barang bukti narkotika.

Peran serta masyarakat dalam upaya penanggulangan tindak pidana narkotika juga terdapat dalam Peraturan Presiden Republik Indonesia Nomor 23 Tahun 2010 Tentang Badan Narkotika Nasional Pasal 49:

"dalam rangka memberikan kesempatan yang seluas-luasnya kepada masyarakat untuk berperan serta dan membantu pelaksanaan P4GN, BNN dapat memfasilitasi dan mengkoordinasikan pembentukan wadah peran serta masyarakat.

Pasal 50 menyebutkan:

"wadah peran serta masyarakat sebagaimana dimaksud dalam Pasal 49 dapat berupa forum, koordinasi, pusat pelaporan dan informasi, serta wadah lainnya sesuai kebutuhan.

Peran serta masyarakat yang diwadah dan difasilitasi oleh BNN dapat menjadi landasan karena masyarakat mempunyai legitimasi dan memperkuat keikutsertaan masyarakat untuk melakukan pencegahan dan pemberantasan narkotika. Peran serta masyarakat juga tertuang dalam Inpres No. 12 Tahun 2011 tentang Pelaksanaan dan Strategi Nasional Pencegahan Dan Pemberantasan Penyalahgunaan dan Peredaran Gelap Narkotika (Jakstranas P4GN) Tahun 2011-2015. Dengan adanya Inpres ini diharapakan upaya masyarakat dalam penanggulangan tindak pidana narkotika dapat terlaksana dengan baik dan didukung oleh berbagai pihak. Pada konsepnya semua aturan yang ada sebagai pendukung tindakan masyarakat untuk menjalankan pencegahan dan pemberantasan penyalahgunaan narkotika.

Sulitnya pencegahan dan pemberantasan tindak pidana narkotika salah satunya sangat berkaitan dengan budaya siri(malu) bagi orang-orang Bugis, sebagian besar masyarakat Bugis masih merasa jika salah anggota keluarganya yang menjadi pelaku penyalahguna narkotika apalagi yang menjadi pelaku adalah anak, hal tersebut dipandang sebagai aib keluarga yang hanya boleh diketahui dan penanganannya juga dilakukan oleh internal keluarga saja. Dalam hal ini korban, keluarga atau masyarakat belum siap untuk mengungkap pelakunya yang merupakan anggota keluarga atau sanak keluarga. Hal yang mendasar dari 
tingginya tingkat penyalahgunaan narkotika adalah factor tingkat pendidikan dan pemahaman tentang agama disinilah peran keluarga dalam meberikan pendidikan non formal. Semakin tinggi tingkat pendidikan seseorang akan cenderung untuk tidak melakukan hal-hal yang membahayakan diri, keluarga dan lingkungan sekitarnya ditambah lagi pemahaman agama yang cukup akan membawa seseorang untuk menjauhi sesuatu yang sifatnya haram. Tindak pidana penyalahgunaan narkotika oleh anak dalam masyarakat ada yang dilaporkan, diproses dan ada juga yang tidak dilaporkan, bahkan jumlah yang tidak dilaporkan masih lebih banyak sehingga menjadi kejahatan yang bersifat tersembunyi (hidden crime). Suatu fakor penting dalam menganalisis kejahatan adalah tingkat dukungan atau sanksi dari masyarakat terhadap kejahatan. Kalau unsur kebudayaan dari suatu masyarakat itu sendiri yang menilai sebagai suatu perbuatan yang legal, maka akan menimbulkan akibat secara langsung bagi para pelaku kejahatan itu akan merasa tidak bersalah.

Faktor terpenting selanjutnya adalah faktor sarana dan prasarana pendukung. Tanpa adanya sarana atau fasilitas pendukung, maka tidak mungkin penegakan hukum akan berlangsung dengan lancar.
Sarana dan prasarana pendukung antara lain mencakup, tenaga manusia yang berpendidikan dan terampil dalam upaya pencegahan dan pemberantasan narkotika di kalangan anak-anak, organisasi yang baik, peralatan yang memadai, keuangan yang cukup dan seterusnya. Kalau hal-hal tersebut tidak terpenuhi, maka mustahil penegakan hukum akan tercapai tujuannya. Atau dengan kata lain, tanpa adanya dukungan sarana maka mustahil upaya pencegahan dan pemberantasan penyalahgunaan narkotika dikalangan anak dapat dilakukan.

Perilaku menyimpang yang dilakukan oleh anak dalam masyarakat perlu di tanggulangi. Dalam teori hukum pidana ada dua bentuk yaitu upaya represif dan upaya preventif. Upaya represif biasa juga disebut tindakan penal (criminal justice procedure) adalah upaya penanggulangan melalui prosedur hukum yang berlaku. Sedangkan tindakan preventif biasa juga disebut tindakan non penal (criminal justice system).

Secara teoritis, pada dasarnya semua ketentuan perundang-undangan mempunyai tujuan. Hukum pidana sebagai salah satu intrumen hukum mempunyai tujuan yaitu sebagai control perilaku setiap orang, oleh karena itu hukum pidana lebih banyak bersifat control perilaku setiap orang, selain 
itu juga bertujuan untuk memberikan ancaman pidana kepada setiap pelaku. Demikian pula Undang-Undang Nomor 35 Tahun 2009 tentang Narkotika dan dikaitkan dengan Undang-Undang Nomor 11 Tahun 2012 tentang Sistem Peradilan Anak tujuan utamanya adalah memberikan perlindungan hukum bagi anak sebagai pelaku/korban penyalahgunaan narkotika. Kebijakan kriminalisasi dari UU Narkotika tidak terlepas dari tujuan UU itu, terutama tujuan (a) untuk mencegah terjadinya penyalahgunaan narkotika dan (b) memberantas peredaran gelap narkotika. ${ }^{7}$

Agar upaya perlindungan hukum terhadap anak sebagai pelaku/korban dapat terlaksana secara optimal maka dibutuhkan kaidah social lainnya, seperti nilai atau norma agama diperkuat untuk melengkapi kaidah hukum. Penyelesaian kasus penyalahgunaan narkotika oleh anak dalam arti upaya represif tidak hanya melalui model perlindungan hukum melalui "criminal justice procedure" akan tetapi dibutuhkan upaya represif lain berupa "criminal justice system" upaya ini dilakukan dengan cara pengembangan Kelembagaan Masyarakat sebagai upaya

\footnotetext{
${ }^{7}$ Barda Nawawi Arief, Masalah Penegakan Hukum dan Kebijakan Hukum Pidana dalam Penanggulangan Kejahatan, (Jakarta. Kencana Prenadamedia Group, 2007) hlm. 195.
}

peningkatan peran serta masyarakat dalam upaya pencegahan dan pemberantasan narkotika di kalangan anak menurut kultur masyarakatnya.

Dalam melakukan pencegahan penyalahgunaan narkotika, upaya yang paling strategis adalah melalui sarana non penal sebab menghindari jauh lebih baik dari pada mengobati. Sedangkan sarana penal dipandang masih mempunyai keterbatasanketerbatasan dalam menanggulangi peyalahgunaan narkotika oleh anak. Upaya ini lebih efektif dilakukan mengingat kondisi masyarakat Indonesia masih terikat dengan nilai-nilai socialbudaya. Dilihat dari sisi upaya non penal ini berarti, perlu digali, dikembangkan dan dimanfaatkan seluruh potensi dukungan dan partisipasi masyarakat dalam upaya untuk mengefektifkan dan mengembangkan "extra legal system"atau "informal and traditional system"yang ada di masyarakat. ${ }^{8}$

Pencegahan penyalahgunaan narkotika sebagai upaya preventif tidak dapat dilepaskan dari keterlibatan setiap komponen dalam masyarakat. Secara normative UU No. 35 Tahun 2009 tentang Narkotika telah melibatkan tiga komponen pokok untuk menjadi pilar pencegahan

\footnotetext{
${ }^{8}$ Ibid., hlm. 52.
} 
penyalahgunaan narkotika khususnya oleh anak yaitu aparat penegak hukum, pemerintah, dan masyarakat. Ketiga komponen ini melibatkan diri dalam pencegahan dan pemberantasan tindak pidana narkotika. Namun dalam prakteknya, ketiga komponen tersebut tidak berjalan secara sinergis dalam mengupayakan tindak preventif. Upaya pencegahan dan pemberantasan narkotika dalam masyarakat tidak dapat dilepaskan dari ketiga komponen tersebut. Aparat penegak hukum yang diberikan kewenangan untuk bertindak secara preventif dengan cara melakukan pengawasan terhadap gejala-gejala yang dapat menciptakan tindak pidana khususya penyalahgunaan narkotika. masyarakat berperan serta secara aktif memberikan laporan kepada aparat penegak hukum tentang adanya gejala-gejala dalam lingkungannya. Selanjutnya pemerintah senantiasa mengontrol, memfasilitasi dan memahami secara detail kondisi masyarakat.

Upaya pertama yang harus dilakukan adalah dengan cara memberikan pendidikan kepada semua keluarga berupa pendidikan non-formal. Cara ini dapat dilakukan dengan memberikan pelajaran tambahan tentang pentingnya pemahaman tentang agama, budaya masyarakat disekitarnya, dan hukum. Sebab anak yang melakukan penyalahgunaan narkotika adalah mereka yang mempunyai latar belakang pendidikan yang rendah sehingga mereka sangat sulit untuk mengendalikan perasaan dirinya. Tujuan pendidikan non penal tidak hanya dapat membentuk watak dan kepribadian luhur seseorang akan tetapi dapat pula meningkatkan derajat keimanan dan ketaqwaan seseoarang kepada Sang Pencipta. Strategisnya peranan pendidikan agama dan berbagai bentuk media penyuluhan keagamaan dalam memperkuat kembali keyakinan dan kemampuan manusia untuk mengikuti jalan kebenaran dan kebaikan. Dengan pendidikan dan penyuluhan agama yang efektif, tidak hanya diharapkan terbinanya pribadi manusia yang sehat jiwa/rohaninya tetapi juga terbinanya keluarga yang sehat dan lingkungan social yang sehat. Pembinaan dan penggarapan kesehatan jiwa masyarakat memang tidak berarti semata-mata kesehatan rohani/mental, tetapi juga kesehatan budaya dan nilai nilai pandangan hidup kemasyarakatan.

Upaya selanjutnya adalah penyuluhan hukum mengenai bahaya dan ancaman pidana bagi penyalahgunaan narkotika yang dilarang oleh Undang-Undang No. 35 Tahun 2009 tentang Narkotika tujuan utamanya adalah pemberian pemahaman kepada 
masyarakat pada umunmnya dan anak pada khususnya untuk dapat membedakan mana perilaku yang melanggar hukum dan mana yang tidak.Selanjutnya penyuluhan tentang nilai-nilai atau norma-norma social sehingga masyarakat mengetahui perbuatan mana saja yang termasuk perbuatan yang berbahaya bagi keamanan masyarakat terutama bagi anak. Pentingnya ilmu pengetahuan bagi anak sebagai pelaku dan/atau korban penyalahgunaan narkotika atau calon penyalahguna narkotika mengingat dalam persfektif kriminologi bahaya laten bagi setiap orang adalah kurangnya pengetahuan tentang kejahatan.

Menjalin komunikasi social yang baik antara aparat penegak hukum dan masyarakat akan meningkatkan hubungan kerja untuk kepentingan pencegahan dan pemberantasan narkotika. hal terpenting adalah masyarakat harus mengubah pemahaman mereka terhadap issu bahaya penyalahgunaan narkotika oleh anak dan mengubah cara pandang mereka terhadap kinerja aparat penegak hukum. Dalam menjalangkan fungsi dan wewenangnya aparat penegak hukum harus dapat merealisasikan nilai dasar hukum (keadilan, kemanfaatan dan kepastian hukum) semakin optimal kinerja aparat penegak akan berpengaruh terhadap kepercayaan dan perilaku social masyarakat.

\section{KESIMPULAN}

Berdasarkan pada uraian dalam hasil penelitian dan pembahasan di atas maka dapat dirumuskan suatu kesimpulan bahwa upaya penanggulangan penyalahgunaan narkotika oleh anak sudah berjalan, namun belum efektif, hal tersebut diketahui dari jumlah anak yang melakukan penyalahgunaan narkotika masih terus meningkat baik secara kualitas maupun kuantitas dari tahun ke tahun. Selain itu, harmonisasi aparat penegak hukum dan peran serta masyarakat masih belum optimal, sehingga hasil yang diharakan belum bisa terwujud, bahkan ada anak yang bukan saja sebagai korban tapi juga sebagai pecandu dan pengedar narkotika. Dan Faktor-faktor yang mempengaruhi efektivitas upaya penanggulangan narkotika oleh anak adalah faktor cara pandang aparat penegak hukum dalam upaya penanggulangan penyalahguna narkotika oleh anak masih berorientasi pada upaya penal. Pemahaman dan pandangan (budaya) masyarakat tentang bahaya laten penyalahgunaan narkotika oleh anak masih minim dan masyarakat masih beranggapan bahwa upaya penanggulangan narkotika adalah kewajiban aparat penegak hukum hal 
ini dipengaruhi oleh tingkat kepercayaan masyarakat terhadap aparat penegak hukum masih rendah. Belum optilmalnya peran serta masyarakat disebabkan oleh hubungan kerja antara aparat penegak hukum dengan masyarakat belum berjalan baik. Ketersediaan fasilitas sarana dan prasarana yang mendukung upaya penanggulangan penyalahgunaan narkotika oleh anak masih terbatas seperti dukungan anggaran.

\section{DAFTAR PUSTAKA}

Ilmar, Aminuddin. Membangun Negara Hukum Indonesia. Makassar, Phinatama Media, 2014.

Badan Narkotika Nasional. Petunjuk Teknik Advokasi Bidang Pencegahan Penyalahgunaan Narkoba Bagi Lembaga/Instansi. Jakarta: BNN RI, 2010.

Nawawi Arief, Barda. Masalah Penegakan Hukum dan Kebijakan Hukum Pidana dalam Penanggulangan Kejahatan. Jakarta: Kencana Prenadamedia Group, 2007.

\section{Bunga Rampai Kebijakan} Hukum Pidana: Perkembangan Penyusunan Konsep KUHP Baru. Jakarta: Kencana Prenadamedia Group, 2008.

Hidayati, Nur. "Peradilan Pidana Anak Dengan Pendekatan Keadilan Restorative dan Kepentingan Terbaik Bagi Anak", Jurnal Pengembangan Humaniora, Vol. 13 No. 2, (Agustus 2013) : 146.

Soekanto, Soerjono. Factor-Faktor Yang Mempengaruhi Penegakan Hukum. Jakarta: Rajawali Press, 2007.
Dirdjosisworo, Soejono. Pathologi Sosial. Bandung: Alumni, 1982.

Prasetyo, Teguh Kriminalisasi Dalam Hukum Pidana. Jakarta: Nusa Media, 2011.

Undang-Undang Nomor 35 Tahun 2009 Tentang Narkotika.

Undang-Undang Nomor 11 Tahun 2012 Tentang Sistem Peradilan Pidana Anak.

Peraturan Presiden Republik Indonesia Nomor 23 Tahun 2010 Tentang Badan Narkotika Nasional.

Inpres No. 12 Tahun 2011 tentang Pelaksanaan dan Strategi Nasional Pencegahan Dan Pemberantasan Penyalahgunaan dan Peredaran Gelap Narkotika (Jakstranas P4GN) Tahun 2011-2015. 